\title{
Psychological impact of landscape principles on human beings: A case study of Safari Villas Park Bahria Town, Lahore, Pakistan
}

\author{
Sadia Farooq* \\ Department of Family and Consumer Sciences, University of Home Economics, Lahore-Pakistan \\ *Corresponding author's email: drsadiafaroq@gmail.com, drsadiafarooq@uhe.edu.pk
}

Citation

Sadia Farooq. Psychological impact of landscape principles on human beings: A case study of Safari Villas Park Bahria Town, Lahore, Pakistan. Pure and Applied Biology. Vol. 9, Issue 3, pp1820-1830. http://dx.doi.org/10.19045/bspab.2020.90194

\begin{tabular}{llll}
\hline \hline Received: 24/02/2020 & Revised: 25/04/2020 & Accepted: 08/05/2020 & Online First: 11/05/2020 \\
\hline \hline
\end{tabular}

\section{Abstract}

Landscape, the greenery and plants in the cities to beautify the surrounding and made for environmental benefits. A landscape can also contributes to reduce stress and fatigue in humans. In this scenario, the research is conducted to analyze the human psychological impact of landscape where principles of landscape are properly used, especially in the housing societies recently developed in the last two decades, in Lahore, Pakistan so the Safari Villas Park in Bahria town housing society is selected. In this mixed-method research the data is collected through the observation and pictorial view of the area to analyze the application of the principles of landscape in the park and a questionnaire is filled by the humans who visit park, to know their experiences and their psychological relief. In Safari Vilas Park, unity, balance, harmony, repetition along with other landscape principles are observed. The findings of the questionnaire show that majority of the people agree that there are enough plants and benches, this facility impact positively on their psychological health. They prefer to come there and enjoy its greenery because of mental relaxation. The park is being used for social interaction, exercise, workout, relaxation for elders and kids. The study would help to design parks which satisfy the humans' psychological expectations by the implementation of principles of landscape. The study opens a novel perspective for scholars to think and design urban landscape areas which provide human beings with a place to devote some blissful time.

Keywords: Human beings; Landscape; Principles of landscape; Satisfaction; Views

\section{Introduction}

Landscape is the art of designing and arranging an open space with greenery and plantation which is especially required in urban areas for enhancing the aesthetics. The landscape areas are also used for reducing negative impacts on environment such as decrease in air pollution [1]. Landscape design is a combination of nature and culture of a place and can have a theme to display the design. It is also important because of the raised pollution level and structural buildings in cities. A designed landscape area can elaborate the visual appearance manifestation of people around it, the open spaces, surfaces, screens and capability of adapting and showing features in terms of structural organization e.g., balance, tension, rhythm, proportion and scale [2].

City green land incorporates aesthetical and practical green regions in networks, parks, 
green belts little woods, creature common living space, private nurseries, sports edifices, etc. [3].

The park can serve as an exemplary site to be replicated any time anywhere, along with the help of results for more sites, that's why the study analysed the principles of landscape used in the park and analysis of humans' experiences can help to understand the requirements and demands of the users who want to spend time in parks nearby their houses. The need of sustainable societies in upcoming era is essential in view of scholars who force all countries of the world to have green areas in each housing society and to maintain it. Because we are living around with destructive lethal issue in air, water, or soil yet in addition in plants as the unnatural and inorganic fertilizers which are harmful to the environment harmfulness. It is currently significant than the earlier years to embrace green regions close by with natural compost to help in human wellbeing. The blocked regions with rich number of individuals can have progressively mental ailment even the pressures. The greenery can be effective to reduce stress and tensions from the life of humans. Scene can act effectively to decrease pressure and sicknesses in the life of todays' man [4].

Landscaped areas, parks and green belts provides crossing and passages to residential streets, shopping markets, community centres, schools, hospitals and offices in more gorgeous and comfortable style which make pedestrian effective to use as a passage for people. Responsive. Greenways are always supported materials for healthy human beings and therefore fresh minds. The more we used the green spots the less we use the power vehicles which can contribute to reduce smog, contamination of chemicals, greenhouse gas emissions, and the accidents and additionally reduces stress that are byproducts of driving and travelling in congested areas [5].

The natural land is a blessing in urban areas which create strong and vigorous societies and communities by developing firm regions, in other words give way the progress of the people. Research shows that nearby greenery of the house makes living residents more social in interactions with other neighbours. Community gardens make people stable there to live just because of the green lands [6] which also has habitats of the animals and birds.

Parks are also influencing factor for neighbourhood because of greenery, natural habitat for birds, water features etc incorporate with humans and natural world. It also caters for the social groupings and community benefits [7].

The standard is set to build up a green land territory in understanding society and way of life of the habitants which gradually cause its place for individuals to have it for a walk, sit and appreciate [8].

The basic premise is that the shape of space, form of space-determining elements and appearance e.g. color, texture, shape and lighting in the landscape determine the relation between design and perception. The principles address the form and functioning of three-dimensional landscape space, which creates a spatial lively location [9].

The landscape is present in the form of parks, gardens, road side areas, corporate landscape and residential lawns. Landscape design can be a personal composition or a design of international standards [10].

The green spaces not only look pleasing but also reduce air pollution, greenhouse gas emissions, and the accidents and stress that are by-products of driving. Even these areas are having numerous other positive effects on human such as urban heat reduction, physical activity centre and health status [11].

Green spaces such as parks and forests are essential components of urban ecosystems. They are essential for physical and mental well-being; they are also very important for the health of the environment [12].

There are a few standards, ways, frameworks, which finish up standards of scene, used to have a decent adequate real 
estate parcel by individuals living around and to adapt to the circumstances which can be negative in their life. A recreation centre can be a plan as indicated by the prerequisites of the general public and individuals yet there are a few guidelines and guidelines which are called standards of scene. The eight standards are solidarity, parity, complexity and concordance, shading, change, line, extent, redundancy which consistently function as a helping instrument to build up a scene territory [13, 14].

Unity in landscape is arranging repetition and unity of a plan. Repetition is accustomed to realize unity in structure by repeating like components which incorporate plants and stylistic theme in the park. Balance or equalization is essentially a feeling of uniformity. There are two kinds of balance in plan: symmetrical and asymmetrical balance. In even equalization or symmetrical balance, different sides of the scene are indistinguishable while in asymmetrical, the landscape is adjusted utilizing various components and items which have practically comparable to informal balance [13, 14].

The contrast helps feature certain components in the plan, while harmony enables components in a landscape to look unified. Contrasting components draw the viewers' consideration when they're put alongside one another. Colors and Shades give the landscape plan the element of reality. Warm hues (for example red and orange) appear to propel, causing an article to appear to be nearer. While cool hues like blues and greens appear to move away from somebody. Transition is basically a continuous change. Transition in a scene configuration is shown step by step fluctuating the plant size or the shading force. The line is the mother of all components in the landscape design. Lines are utilized wherever including making beds, gateways, walkways, surface, and point of view. Lines are additionally used to give an illusion of depth and distance. Proportion alludes to the size of a component in connection to the next. Among the principles of landscape, this is the clearest one yet at the same time needs a bit of arranging and thought. One must guarantee that every one of the components in a scene configuration has legitimate extents $[13,14]$.

An excessive number of items that are not related can make your plan look impromptu and jumbled. Additionally, don't abuse a component since utilizing a component can make your structure feel exhausting, uninteresting, and dull. There is wonderful redundancy in the assortment of plants in the recreation place. According to the demand of contemporary era, every inch of land is important to reduce negative effects caused by human activities including urban heat island effect and also for therapeutic impacts [13-17].

It is very much obvious that a natural scene impact positively on humans but the research is different in the field because the study focused on implication of landscape principles and their impact on human's relaxation.

The human's psychological health is being affected in the congested cities and having negative results. At the same time, the landscape areas are also being developed and previously present which shows that the time spend in a park is considered leisure time for a person which also reduce stress [18]. A study was conducted on humans to see their rise in motivational derives in Sheffield, UK which resulted the obvious change in their behaviour which was observed in parks [19]. In the last century, the parks were consciously designed, to give open spaces to people with a strong association of health benefits for humans [20].

The studies have shown that the landscape is precious for urban development along mental wellbeing of people $[16,17]$ but the humans' views according to Pakistan region are less documented and even the areas are present but the worth of that area must be registered from the humans' psychological point of view, which can help 
for other new and developing housing societies.

Safari Villas Park Bahria Town Lahore (Fig. 1) was selected for the case study, the park is generally known as Safari park by the locals so the same name is mentioned in the study. The reason to choose the Safari park is that it is situated in centre of the housing society with a modern look where neighbouring humans come for physical activities which give them relaxation and socialization.

The objectives of the study are as follows:

- To analyse the principles of landscape applied in Safari Park Bahria Town Lahore, Pakistan.
- To analyse the humans' psychological impact based on their experience in Safari Park Bahria Town Lahore, Pakistan.

- To analyse the use of landscape principles and their relation to humans' psychological impact.

The park which was selected, built purposefully to bring back the spirit of the land of the greens with a modern touch. The master design revives the communal setting alongside the famous Lahore Canal. Bahria Town Lahore developments (Fig. 1) form the juncture of a rich cultural \& architectural history to a bright and progressive future [21, 22].

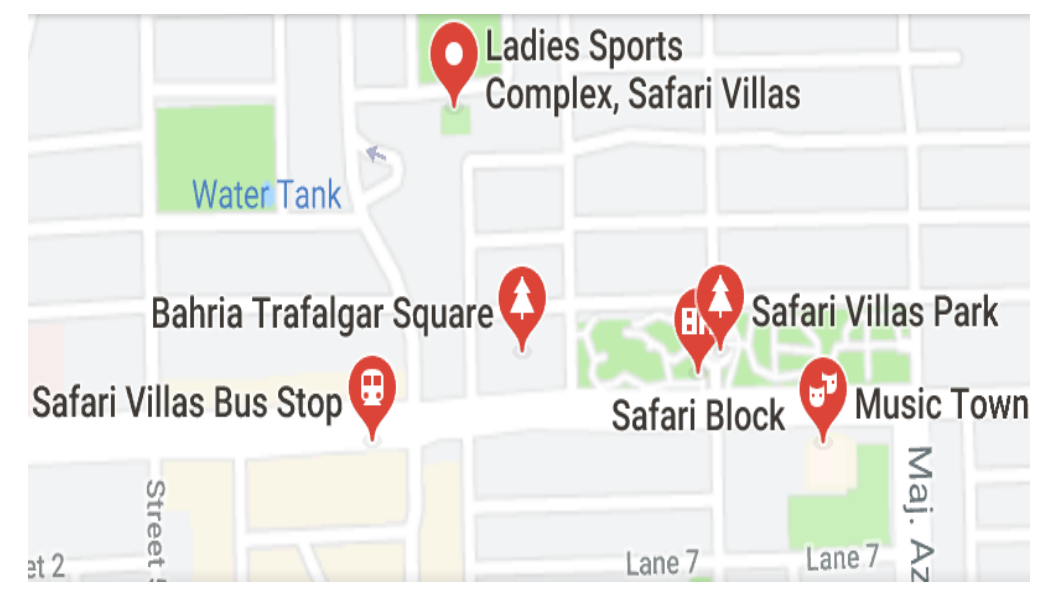

Figure 1. Location of Safari Villas Park, Bahria Town, Lahore, Pakistan

\section{Materials and methods}

It was a mixed method research in which the data had been collected through the observation (record keeping by researcher herself and researcher data collection through her visit to the place) and pictorial view of the park to analyse the presence and application of the principles of landscape in the park. A survey (questionnaire was given to the humans) was also conducted through a questionnaire which was filled by the humans who came in the park. The questionnaire was about to know their experience, feelings and satisfaction level of humans in the Safari Park Bahria Town Lahore. The five-point Likert scale was used for the assessment of the human's views ranges from 1 to 5, 1-strongly agree,
2 agree, 3 neutral, 4 disagree, 5 strongly disagree.

The landscape architect along with the supporting staff such as gardeners and workers also helped to survey landscape features of the Park. The pictures were taken at the day and night time and questionnaire were given to humans at afternoon and evening in the month of October (October is considered pleasant with sunshine and cool breeze in Lahore, Pakistan) when a rush of people gather there.

\section{Universe}

The universe of the study was the humans coming in landscape areas in housing societies of urban zones developed in near last twenty years with contemporary look, especially parks in Lahore, Pakistan. 


\section{Sample}

Safari Park situated inside the Bahria Town housing society; Lahore was selected as a case in Pakistan. The Bahria Town housing society was established after 2000s, its design was influenced by GrecoRoman culture and is having a lot of lush green areas [21, 22]. The humans come there in the garden for walk, to sit, to talk and to exercise or play.

\section{Results}

Analysis and interpretation of Principles of Landscape Design Applied in the Safari Park.

The analysis of the principles of landscape design in Safari park is conducted and concluded on the observation and pictorial views.

\section{Unity}

In Safari Park, it observed that the unity was present in the form of plants, benches and fountains (Fig. 2 to 4). Some kinds of plants were repeated in the park and use of fountains on equal distance and benches of same color and style also represented unity in the park. The only one type of lighting fixtures were used which also add in the unity of the park as a principle of landscape (Fig. 5).

There was asymmetrical balance present in the form of pathways and fountains (Fig. 2 \& 3) and symmetrical balance was represented in the repeated same parts of the pond of water (Fig. 4) in the park.

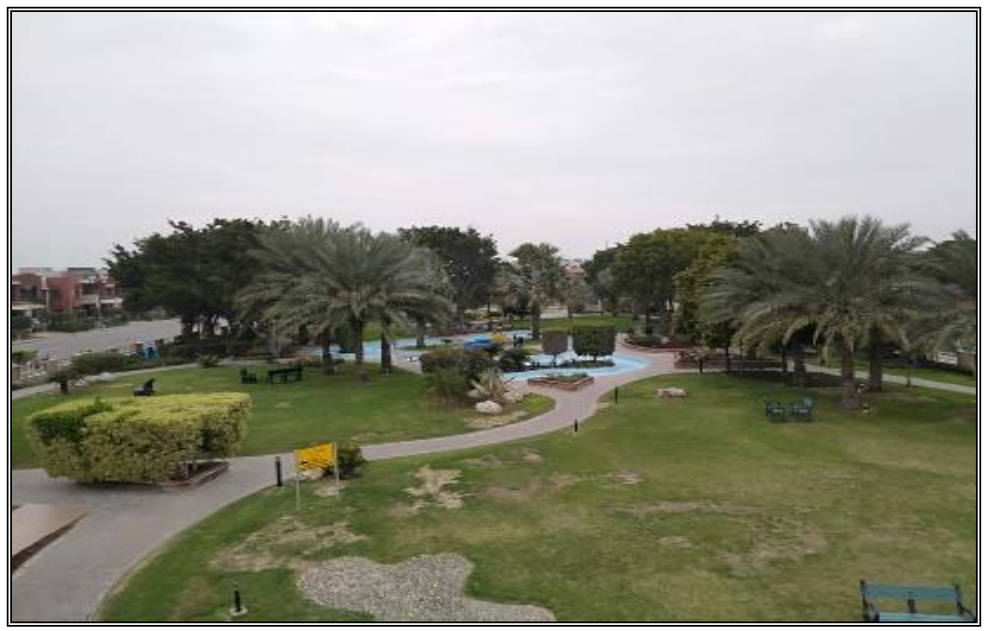

Figure 2. Grouping of trees, benches, pathways in safari park

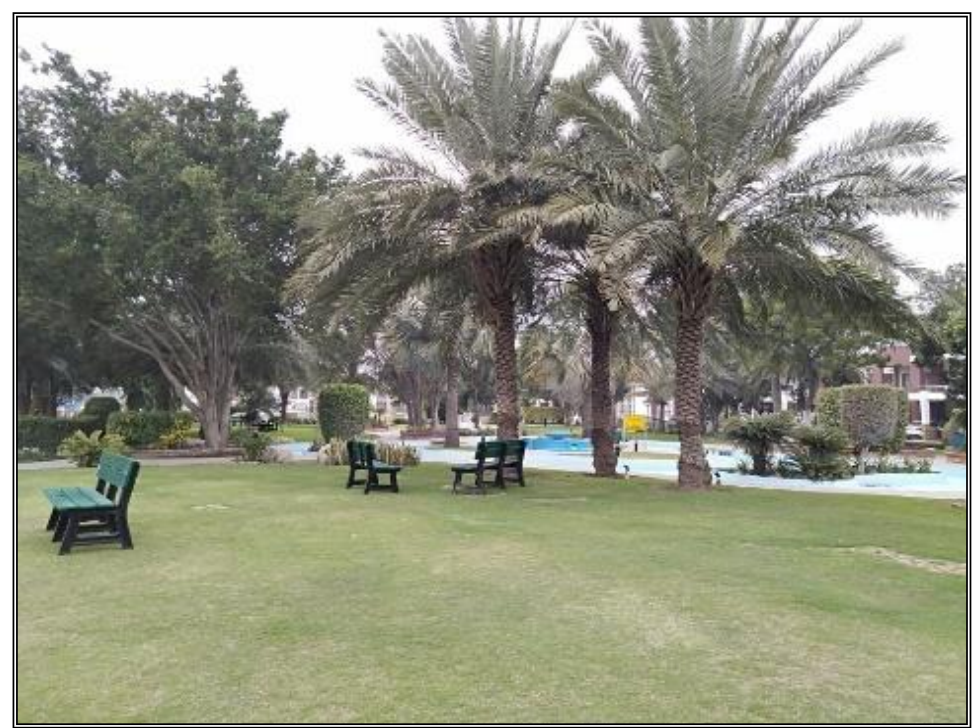

Figure 3. Benches with green color on grass in safari park 


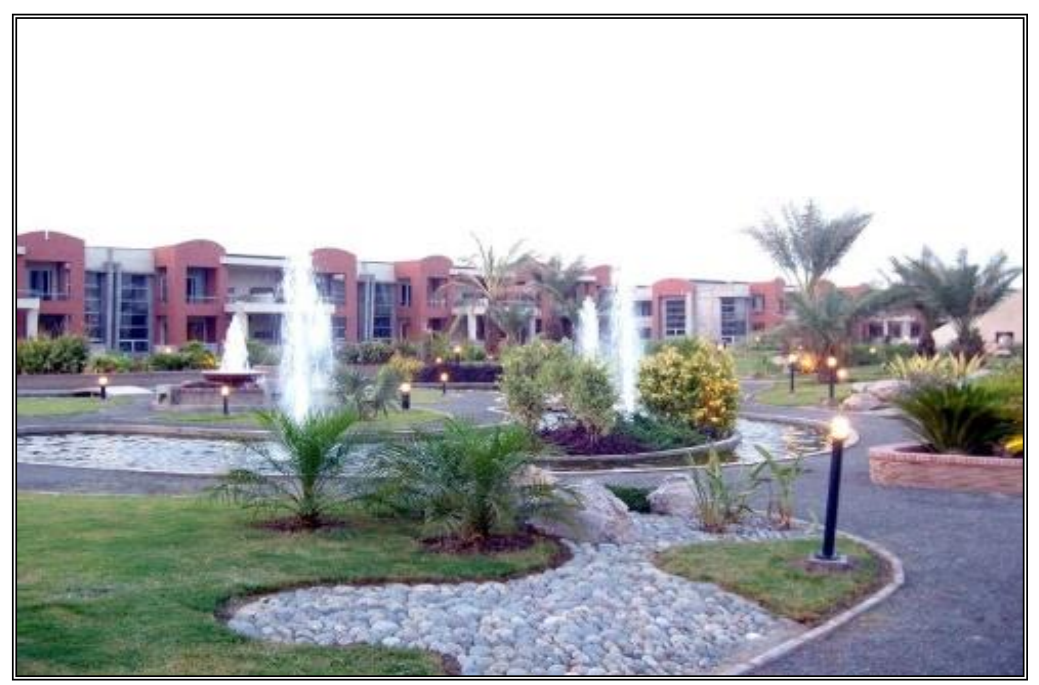

Figure 4. Irregular shapes made of pebbles and fountains in safari park

\section{Contrast and harmony}

The overall design of the park is harmonized with the help of kinds of plants, the placement at equal distance. There is contrast between the blue ponds and green plants which highlight the contrast through color (Fig. 2 \& 6). Harmony was present in the form of unified look of tall date trees and placement of other plants (Fig. $2 \& 3$ ).

Emphasis

While surveying the hardscape of Safari Park Bahria Town, the emphasis was found in curve shape of the pathways with tuff tiles, benches with green color and fountain itself was emphasizing because of its water feature (Fig. 2, $3 \& 6$ ).

Color

Basically, the tints and shades of green color were a part of any green area but use of blue tiles for ponds (Fig. 6) also enhance the both green and blue colors. Yellow color was used for informative boards (Fig. $2 \& 4$ ), yellow itself is an arousing color which can be seen from a distance Green color of benches (Fig. 3) was also harmonizing with the grass. Lighting color at the evening time also enhanced the ambience in the park (Fig. 5).

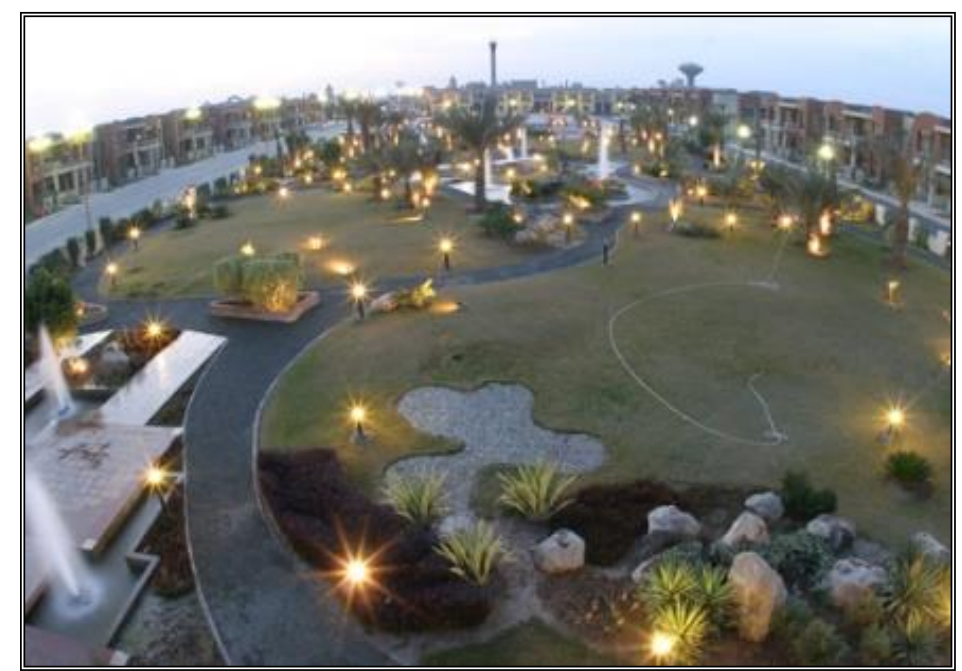

Figure 5. Lighting in safari park Bahria Town

\section{Transition}

There was a gradual transition in the texture, foliage shape and size of different plants in the park (Fig. 4). A gradual alteration in height of trees and plants and 
changing color intensity, which also follow the principle of transition (Fig. $4 \& 6$ ).

Line

Straight tall date trees were used all over the park to highlight the natural hugeness (Fig. 2, 4 \& 6) like a forest and give it a feeling of strength. Lines were also used almost everywhere including creating beds, entryways and walkways (Fig. 2, 3 \& 6). Lines were also used to give an illusion of depth and distance such as in pond, trees and foliage (Fig. 3, 4 \& 6). Curved lines were used in the pathways and fountains in the park (Fig. 4, $6 \& 7$ ).

\section{Proportion}

Proportion refers to the size and scale of an element in relation to the other is visible in tree selection (Fig. 2). Even proportion maintenance is difficult in natural plant growth but cutting and hedging give the park a neat look (Fig. 2, $3 \&$ 6) One must ensure that all the elements in a landscape design have proper proportions.

The proportions in the park was well planned the size of areas and the size of soft and hard scape was appropriate according to each other. The amount of space between all different elements was also organized and providing room to humans (Fig. 2).

\section{Repetition}

Repetition was very softly applied in the park in form of trees, benches and color (Fig. 2-4 \& 6) and too many variations were avoided which could make design look unplanned and cluttered. The lighting fixtures of one kind were also repeated in the park (Fig. 5).

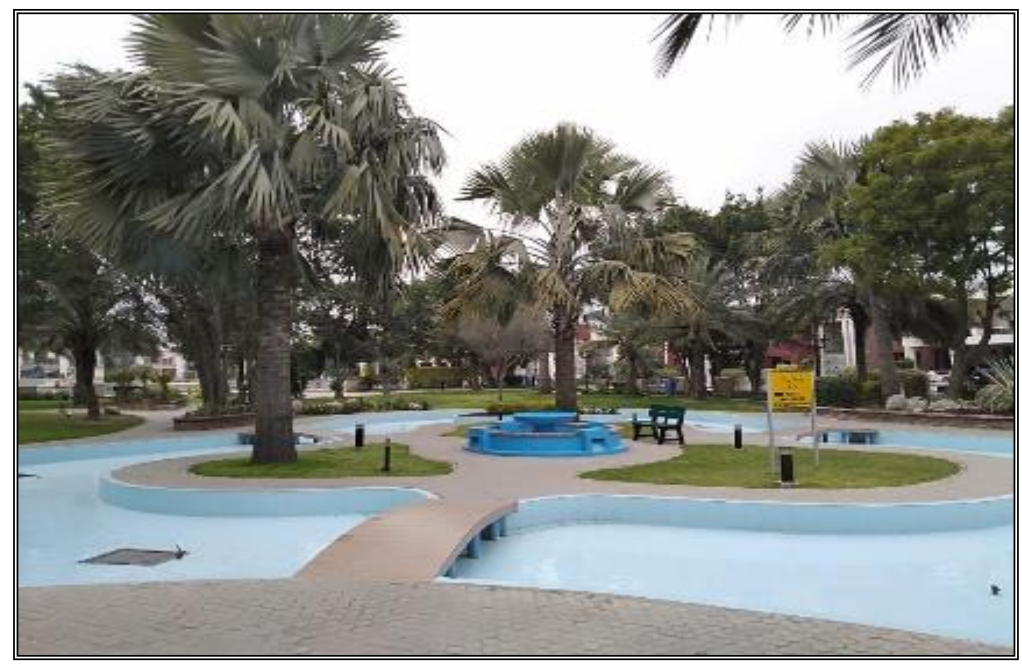

Figure 6. Water pond with light blue surface in safari park

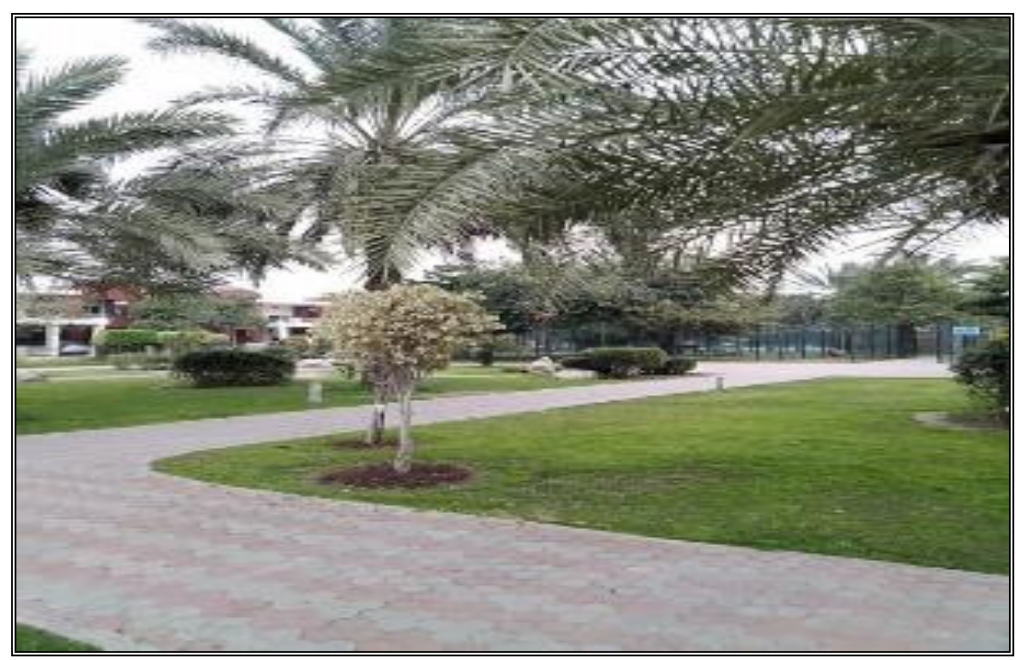

Figure 7. An emphasis path ways in curved lines in safari park 
Analysis and interpretation of survey of landscape in the safari park

The questionnaire was filled by 100 humans who came in Safari Park for different activities and their answers were concluded on the percentages. The humans who were willing to fill the questionnaire were selected with age groups ranges from 18 years to 56 years from both female and male.

The results in (Table 1) shows that 50\% people agree and $23 \%$ are strongly agree that they visit Safari Park Bahria Town and feel happy, $60 \%$ people agree and $37 \%$ strongly agree that there are enough plants and flowers in the park which give them pleasure, $40 \%$ people agree and $23 \%$ strongly agree that the hardscape area for sitting is enough which make them feel spaciousness in the park, 63\% people strongly agree and $37 \%$ agree that this landscape has a positive impact on their psychological health.

$57 \%$ people agree and $40 \%$ strongly agree that their anxiety level reduces while staying there. $57 \%$ people strongly agree and $30 \%$ agree that the park is clean and well maintained which raise their motivational level. $47 \%$ people agree and $43 \%$ strongly agree that the park has a good atmosphere for children who feel happy to play in it.

$47 \%$ people agree and $43 \%$ strongly agree that the natural environment of the park is being protected by the use of unity and balance. $47 \%$ people strongly agree and $27 \%$ people agree that proper trash containers are available there which give a feel of cleanliness and freshness. $40 \%$ people agree and $27 \%$ strongly agree that the park is not too crowded but is good for socialization.

Table 1. Responses of Humans in Safari Park

\begin{tabular}{|c|c|c|c|c|c|c|}
\hline S.No. & Statements & $\mathbf{1}$ & $\mathbf{2}$ & $\mathbf{3}$ & $\mathbf{4}$ & $\mathbf{5}$ \\
\hline 1 & I feel happy to visit Bahria Town Safari Villas Park. & 23 & 50 & 27 & 0 & 0 \\
\hline 2 & $\begin{array}{c}\text { The number of plants and flowers in the park are well arranged } \\
\text { and give me pleasure }\end{array}$ & 37 & 60 & 3 & 0 & 0 \\
\hline 3 & $\begin{array}{c}\text { There is enough hardscape area for sitting like benches which } \\
\text { make me feel spaciousness in the park. }\end{array}$ & 23 & 40 & 23 & 10 & 23 \\
\hline 4 & $\begin{array}{c}\text { I feel like this landscape has a positive impact on my } \\
\text { psychological health. }\end{array}$ & 63 & 37 & 0 & 0 & 0 \\
\hline 5 & I feel that my anxiety level reduces while staying here. & 40 & 57 & 3 & 0 & 0 \\
\hline 6 & $\begin{array}{c}\text { The park is clean and well maintained which raise my } \\
\text { motivational level. }\end{array}$ & 57 & 30 & 10 & 0 & 3 \\
\hline 7 & $\begin{array}{c}\text { The park has a good atmosphere for children who feel happy to } \\
\text { play in it. }\end{array}$ & 43 & 47 & 7 & 0 & 3 \\
\hline 8 & $\begin{array}{c}\text { The natural environment of this park is being protected by the use } \\
\text { of unity and balance. }\end{array}$ & 43 & 47 & 7 & 3 & 0 \\
\hline 9 & $\begin{array}{c}\text { Proper trash containers are available here which give a feel of } \\
\text { cleanliness and freshness. }\end{array}$ & 47 & 27 & 20 & 3 & 3 \\
\hline 10 & The park is not too crowded but is good for socialization. & 27 & 40 & 27 & 6 & 0 \\
\hline 11 & $\begin{array}{c}\text { Overall, I am satisfied with my visit here for my psychological } \\
\text { relaxation. }\end{array}$ & 34 & 60 & 3 & 0 & 3 \\
\hline 12 & $\begin{array}{c}\text { I would like to visit this park again because it gives me mental } \\
\text { relief for some time from worries in life. }\end{array}$ & 47 & 53 & 0 & 0 & 0 \\
\hline
\end{tabular}

*all results are in percentages $(\%)$

$60 \%$ people agree and $34 \%$ strongly agree that they are satisfied with their visit and for their psychological relaxation. 53\% people agreed and $47 \%$ strongly agree that they would like to visit this park again because it gives them mental relief for some time from worries in life. (Fig. 8). 
Rather than this $27 \%$ were not visiting the park frequently but they filled the questionnaire. Even majority was satisfied with provided sitting area but $46 \%$ humans still want to increase the sitting area.

\section{Interpretation of other observed features in the park}

A wide variety of plants such as Song of India, Chir Pine, Boxwood, Snake Plant, Phoenix Palm, Queen Palm, Kangi Palm, Ficus Tree, Spider Plant was present in the park which enhanced the beauty of the place (Fig. 2 to 8 ).

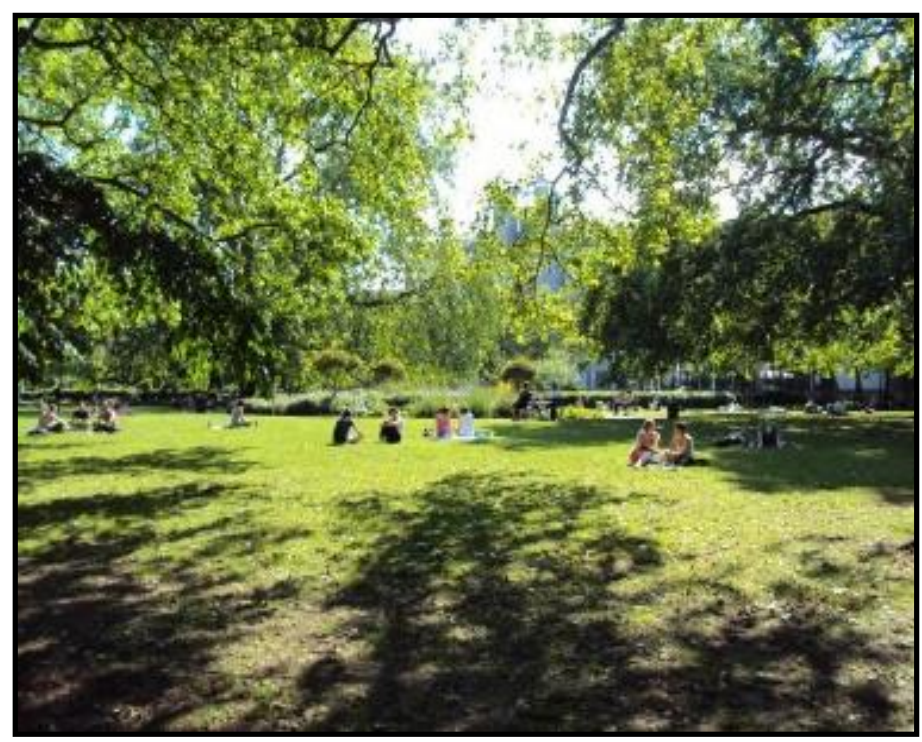

Figure 8. Nature has its own benefits on mental health, reducing stress and increasing happiness

\section{Discussion}

In Safari Park, the unity was present in the types of plants, benches and lighting fixtures. There is asymmetrical balance in the form of fountains in the park. The overall design of the park was harmonized and there was a contrast between the blue fountains and green plants [2]. There was transition in the texture, foliage shape and size of different elements of the park. Curved lines were used in the pathways and fountains in the park. The proportions in the park were well planned and repetition in the variety of plants was present in the park, emphasis was found in the pathways with tuff tiles, wooden benches and fountains [3].

Most of the people agreed that they often visit Safari Park Bahria Town and they think that there were enough plants and benches in the park. Most of the people strongly agreed that this landscape had a positive impact on their health $[4,16]$ and the park was clean and well maintained [13, 14] as proper trash containers were also available in the park. Majority of the people agreed that their anxiety level reduces while staying there, the park was having a good atmosphere [8] for children to play and enjoy swings in the park. The natural environment of the park was being protected. Majority of the people agreed that the park was not too crowded [5-7], they were satisfied with their visit to the park [17] and they were willing to visit this park again. The sitting area need to be increased in the park according to the humans' view.

The results of the use of principles of landscape on human psychological factor were very obvious as people visit the park and feel happy. They also enjoy the plants and flowers in the park which also give them pleasure, the hardscape area for sitting 
was well managed which make them feel spaciousness in the park, the humans also responded that they feel a positive impact on their psychological health and reduction in anxiety. They also agreed that the park was clean and well maintained which raise their motivational level. Even children feel happy to play in it. Humans were agreed that the natural environment of the park is being protected by the use of unity and balance. The availability of trash containers also gives feeling of cleanliness and freshness and good for socialization. Humans also feel psychological relaxation and they would like to visit the park again because it gives them mental relief for some time from worries in life [18-20].

The questionnaire was not given to the people who were not coming to the park so it is recommended for the future study to include people who did not visited the park to know the reasons that why they are not interested to come to the parks.

\section{Conclusion}

The research on landscape area was conducted to find out its human psychological impact when principle of landscape used, specifically in recently established housing societies e.g. Safari Villas Park in Bahria town housing society. This mixed method research focused on observation and pictorial view of the area to analyze landscape psychological impact on humans along with a questionnaire filled by the human beings who come there. In conclusion, Safari Vilas Park has designed according to the principles such as unity, balance, harmony, repetition etc. Majority of the people agreed that the area had enough plants and benches which was relaxing to have that facility. The lighting fixtures, combination of colors of blue and green, foliage shaping, use of curved lines, fountain and other elements in the park were arranged according to the landscape principles. The park was being used for social interaction, exercise, workout, and relaxation. The research is a guideline for the landscape designers, interior designers and architects to design parks which satisfy the humans' psychological expectations by the implementation of principles of landscape in the parks.

\section{Authors' contributions}

Conceived and designed the experiments: $S$ Farooq, Performed the experiments: $S$ Farooq, Analyzed the data: S Farooq, Contributed materials/ analysis/ tools: S Farooq, Wrote the paper: S Farooq.

\section{Acknowledgment}

The researchers express their deepest appreciation to the staff of Bahria Safari who provided all the possibilities to complete the research.

\section{References}

1. Hyams E (1970). A History of Gardens and Gardening. New York, Washington: Praeger Publishers. pp 239.

2. Sanderson J (2019). Landscape ecology: a top down approach. CRC Press.

3. Kenijnendijk CC, Ammerstedt $\mathrm{M}$, Nielsen $\mathrm{AB} \&$ Maruthaveeran $\mathrm{S}$ (2013). Benefits of Urban Parks: A Systematic Review. Copenhagen Copenhagen and Alnarp.

4. Jellicoe $G$ \& Jellicoe S (1987). The landscape of man: shaping the environment from prehistory to the present day (pp 8). New York: Thames and Hudson.

5. Spiegelhalter K, Ruswick $\mathrm{T} \&$ Noto $\mathrm{P}$ (2019). Environmental Justice: Landscape Architecture, A students' Guide. Cornell University, Ithaca, New York,

USA.Retrievedon $22^{\text {nd }}$ Oct.2019fromhtt ps://www.asla.org/uploadedFiles/CM

S/PPNs/Landing_Pages/StudentsGuid e_EnvJustice_Draft.pdf

6. Gies E (2006). The health benefits of parks. The Trust for Public Land, 1-24. 2006.

7. Kyle GT, Mowen AJ \& Tarrant M (2004). Linking place preferences with place meaning: An examination of the relationship between place motivation and place attachment. $J$ of Environ Psychol 24(4): 439-454. 
8. Benninger CC (2002). Principles of intelligent urbanism: The case of the new Capital Plan for Bhutan. Ekistics 60-80.

9. Boults E \& Sullivan C (2010). Illustrated history of landscape design. John Wiley \& Sons.

10. Makhelouf A (2009). The effect of green spaces on urban climate and pollution. $J$ of Environ Health Sci \& Engin 6(1): 35-40.

11. Troll C (2007). The geographic landscape and its investigation. Foundation Papers in Landscape Ecol 71-191.

12. Antrop M (2000). Geography and landscape science. Belgeo. Revue Belge de Géographie (1-2-3-4): 9-36.

13. Cadenasso ML \& Pickett ST (2008). Urban principles for ecological landscape design and maintenance: scientific fundamentals. Cities and the Environ (CATE) 1(2): 4.

14. Robert H \& Jamie L (2014). Landscape Architecture: An Introduction. University of Newcastle-upon-Tyne, London,England.https://lib.hpu.edu.vn /handle/123456789/22817.

15. Jones PD, Groisman PY, Coughlan M, Plummer N, Wang WC \& Karl TR (1990). Assessment of urbanization effects in time series of surface air temperature over land. Nature 347(6289): 169.

16. Taheri S, Shabani A, \& Sichani MG (2019). The Role of Therapeutic Landscape in Improving Mental Health of People with PTSD. In Psychological Trauma. Intech Open.
17. Bratman GN, Anderson CB, Berman MG, Cochran B, De Vries S, Flanders J \& Kahn PH (2019). Nature and mental health: An ecosystem service perspective. Sci Adv 5(7): Eaax0903.

18. Orsega-Smith E, Mowen AJ, Payne LL \& Godbey G (2004). The interaction of stress and park use on psychophysiological health in older adults. $J$ of Leisure Res 36(2): 232-256.

19. Irvine KN, Warber SL, Devine-Wright P \& Gaston KJ (2013). Understanding urban green space as a health resource: A qualitative comparison of visit motivation and derived effects among park users in Sheffield, UK. Inter J of Environ Res and Pub Health 10(1): 417-442.

20. Maller C, Townsend M, St Leger L, Henderson-Wilson C, Pryor A, Prosser L \& Moore M (2009). Healthy parks, healthy people: The health benefits of contact with nature in a park context. In The George Wright Forum 26(2): 51-83).

21. Information of Safari Park Bahria Town, Lahore https://www.google.com/search?rlz=1 C1DVJR_enPK802PK802\&sxsrf=AC YBGNQBDgpRGJrr2CcP228_ZKJTu 2zI0w:1568703023832\&q=safari+par $\mathrm{k}+$ bahria+town+lahore... Retrieved on $25^{\text {th }}$ Sep 2019.

22. Parks and Zoos, Bahria Town, retrieved on $17^{\text {th }}$ September 2019fromhttp://www.bahriatown.com/ index.php?option=com_content $\&$ task $=$ view $\&$ id $=346 \&$ Itemid $=127$. Retrieved on $17^{\text {th }}$ Sep. 2019. 